\title{
Upaya Penerapan Model Pembelajaran JIGSAW Untuk Meningkatkan Pemahaman Konsep Geografi Pada Materi Dinamika Hidrosfer Kelas X.3 SMA Negeri 1 Kademangan Kabupaten Blitar
}

\author{
Tiya Yuda Hananingsih*, Ach. Amirudin**, Juarti** \\ *Pendidikan Geografi, Fakultas Ilmu Sosial, Universitas Negeri Malang \\ **Pendidikan Geografi, Fakultas Ilmu Sosial, Universitas Negeri Malang
}

\section{INFO ARTIKEL \\ Riwayat Artikel:}

Diterima: $10-5-2017$

Disetujui: 12-11-2017

\section{Kata kunci:}

Pemahaman konsep geografi; model pembelajaran JIGSAW

\section{Alamat Korespondensi:}

Tiya Yuda Hananingsih

Pendidikan Geografi

Universitas Negeri Malang

Jalan Semarang No. 5 Malang

E-mail: Hanatiyya@yahoo.com

\begin{tabular}{l} 
ABSTRAK \\
\hline Abstrak: Kemampuan siswa untuk belajar geografi \\
berhubungan langsung dengan pemahaman mengenai konsep- \\
konsep dan prinsip-prinsip yang ada dalam mata pelajaran \\
geografi. JIGSAW merupakan salah satu model pembelajaran \\
yang memberi kesempatan siswa untuk belajar dengan cara \\
berkelompok. Model pembelajaran ini dapat membantu siswa \\
untuk memahami suatu konsep maupun materi \\
pelajaran.Penelitian ini dilakukan dengan tujuan untuk \\
meningkatkan pemahaman konsep geografi siswa pada materi \\
dinamika hidrosfer.Subjek penelitian adalah siswa kelas X.3 \\
SMA Negeri 1 Kademangan dengan jumlah siswa \\
30.Penelitian ini merupakan penelitian tindakan kelas yang \\
telah dilakukan selama dua siklus, setiap siklusnya dilakukan \\
dalam dua kali pertemuan.Berdasarkan hasil penelitian yang \\
telah dilaksanakan, diperoleh peningkatan pemahaman konsep \\
geografi siswa melalui penerapan model pembelajaran \\
JIGSAW. Peningkatan pemahaman siswa dari rata-rata \\
pemahaman awal sebelum tindakan sebesar 72,22 , meningkat \\
sebanyak 2,68\%, sehingga rata-ratanya menjadi 74,16 pada \\
siklus I. Dari siklus I ke siklus II rata-rata pemahaman konsep \\
meningkat sebanyak 6,29\%, sehingga rata-ratanya menjadi \\
78,83. Adapun saran dalam penelitian ini yaitu tidak semua \\
siswa cocok belajar dengan penerapan model pembelajaran \\
JIGSAW.Jadi untuk membuat siswa selalu aktif dan antusias \\
di setiap kegiatan belajar diperlukan variasi model \\
pembelajaran.
\end{tabular}

Abstrak: Kemampuan siswa untuk belajar geografi berhubungan langsung dengan pemahaman mengenai konsepkonsep dan prinsip-prinsip yang ada dalam mata pelajaran geografi. JIGSAW merupakan salah satu model pembelajaran yang memberi kesempatan siswa untuk belajar dengan cara berkelompok. Model pembelajaran ini dapat membantu siswa untuk memahami suatu konsep maupun materi pelajaran.Penelitian ini dilakukan dengan tujuan untuk meningkatkan pemahaman konsep geografi siswa pada materi dinamika hidrosfer.Subjek penelitian adalah siswa kelas X.3 30.Penelitian ini merupakan penelitian tindakan kelas yang telah dilakukan selama dua siklus, setiap siklusnya dilakukan dalam dua kali pertemuan.Berdasarkan hasil penelitian yang telah dilaksanakan, diperoleh peningkatan pemahaman konsep geografi siswa melalui penerapan model pembelajaran JIGSAW. Peningkatan pemahaman siswa dari rata-rata pemahaman awal sebelum tindakan sebesar 72,22, meningkat sebanyak 2,68\%, sehingga rata-ratanya menjadi 74,16 pada siklus I. Dari siklus I ke siklus II rata-rata pemahaman konsep meningkat sebanyak $6,29 \%$, sehingga rata-ratanya menjadi 78,83. Adapun saran dalam penelitian ini yaitu tidak semua siswa cocok belajar dengan penerapan model pembelajaran di setiap kegiatan belajar diperlukan variasi model pembelajaran.

\section{PENDAHULUAN}

Pendidikan masih didominasi oleh pandangan bahwa pembelajaran masih berfokus pada guru sebagai sumber utama belajar dan materi pembelajaran adalah kewajiban yang harus mereka hafalkan.Untuk itu, diperlukan sebuah strategi baru yang memberdayakan siswa.Sebuah strategi belajar yang tidak mengharuskan siswa menghafal, tetapi mendorong siswa untuk mamahami semua materi pembelajaran yang mereka pelajari.Proses pembelajaran diharapkan adanya aktivitas siswa, yaitu siswa mampu mengungkapkan 
pendapat sesuai dengan apa yang dipahami serta mampu memahami konsep-konsep dalam materi pelajaran.

Menurut Purwanto (2013) pemahaman merupakan kemampuan menjelaskan fakta, ide, gejala, konsep, dan sebagainya. Apabila seseorang telah mampu menjelaskan hal tersebut, dengan sendirinya ia telah memiliki kemampuan tingkat dasar (pengetahuan) dan juga pemahaman. Belajar pemahaman memiliki kedudukan yang sangat penting.Pemahaman merupakan dasar dari kemampuan yang lebih tinggi seperti aplikasi, analisis, sintesis dan penilaian. Kemampuan tersebut tidak akan tercapai apabila seseorang belum menguasai pemahaman terhadap materi pembelajaran. Apabila seseorang mampu melakukan analisis, maka dengan sendirinya ia telah memiliki kemampuan pemahaman.

Menurut Sagala (2012) konsep adalah "buah pemikiran seseorang atau sekelompok orang yang dinyatakan dalam definisi sehingga melahirkan produk pengetahuan yang meliputi prinsip, hukum, dan teori”. Konsep diperoleh dari fakta, peristiwa, pengalaman, melalui generalisasi dan berfikir abstrak.Konsep dapat mengalami perubahan disesuaikan dengan fakta atau pengetahuan baru.

Pengertian konsep menurut Winkel (1996) yaitu pelambangan dalam bentuk suku kata, yang mewakili suatu pengertian tertentu.Suatu konsep atau pengertian yang diperoleh, dapat dituangkan dalam bentuk lambang verbal.Banyak konsep atau pengertian disimpan dalam ingatan, dalam bentuk lambang verbal atau kata. Semua kata itu, kemudian dapat diingat dan dihubungkan satu sama lain serta menjadi alat dalam berpikir.

Pemahaman konsep merupakan dasar dan tahapan penting dalam rangkaian pembelajaran geografi.Kemampuan siswa untuk belajar geografi berhubungan langsung dengan pemahaman mengenai konsep-konsep dan prinsip-prinsip yang ada dalam mata pelajaran geografi. Konsep adalah suatu hal dasar yang digunakan untuk memulai proses pembelajaran. Siswa yang mampu memahami konsep dengan baik akan lebih mudah memahami suatu pembelajaran dibandingkan dengan siswa yang hanya menghafal konsep.

SMA Negeri 1 Kademangan merupakan salah satu sekolah negeri di Kabupaten Blitar yang mempunyai siswa dengan prestasi belajar yang bervariasi, sehingga penguasaan konsep siswa juga beranekaragam. Salah satunya pada materi pelajaran geografi yang diberikan pada semua kelas X. Berdasarkan observasi awal yang dilakukan pada tanggal 30 Januari 2016 SMA Negeri 1 Kademangan Blitar masih menggunakan Kurikulum Tingkat Satuan Pendidikan (KTSP). Observasi dilakukan dengan mewawancaraiguru geografi SMA Negeri 1 Kademangan Blitar. Berdasarkan hasil observasi tersebut diketahui bahwa pelaksanaan pembelajaran masih didominasi oleh ceramah, sistem penugasan dengan cara mengerjakan LKS dan buku penunjang, berkelompok mengerjakan makalah dan membuat media power point. Kelas $\mathrm{X}$ berjumlah sepuluh kelas dengan satu kelas unggulan dan sembilan kelas reguler. Berdasarkan hasil wawancara dan hasil nilai ulangan harian terakhir sebelum materi dinamika hidrosfer menunjukkan bahwa kelas X.3 memiliki nilai rata-rata ulangan harian sebesar 72,22 sedangkan nilai ketuntasan minimum mata pelajaran geografi adalah 75 .

Terkait dengan permasalahan tersebut, diperlukan suatu pembelajaran yang memungkinkan semua siswa terlibat aktif dan dapat membuat siswa memahamai apa yang telah dipelajarinya. Salah satu alternatif model pembelajaran yang dapat membantu seluruh siswa aktif dan dapat memahami apa yang telah dipelajarinya yaitu dengan pembelajaran kooperatif. Pembelajaran kooperatif menurut Sumarmi (2012), merupakan pembelajaran yang memberikan kesempatan kepada para siswa untuk berkembang secara maksimal, baik perkembangan kognitif, afektif maupun psikomotoriknya.Oleh karena filosofinya, mendidik siswa bukan hanya kognitifnya saja yang berkembang baik, tetapi bagaimana mereka mampu mengaplikasikan pengetahuan dan keterampilannya tersebut seumur hidupnya. 
Penggunaan model pembelajaran dalam kegiatan pembelajaran sangat berpengaruh terhadap pemahaman konsep siswa. Kegiatan pembelajaran yang dilakukan guru geografi di SMA Negeri 1 Kademangan masih menggunakan metode ceramah, yang menyebabkan siswa kurang terlibat dalam proses pembelajaran, sehingga siswa kurang dapat menggali pemahamannya lebih dalam. Perlu diberikannya model pembelajaran yang membuat siswa lebih memahami materi yang di berikan.Model pembelajaran yang dipilih yaitu model pembelajaran kooperatif JIGSAW. Model pembelajaran JIGSAW menurut Rusman (2008 : 203) dalam Shohimin (2014) yaitu "model belajar kooperatif dengan cara siswa belajar dalam kelompok kecil yang terdiri atas empat sampai dengan enam orang secara heterogen dan siswa bekerja sama saling ketergantungan positif dan bertanggung jawab secara mandiri”.

Model pembelajaran kooperatif JIGSAWdipilih karena dalam pembelajaran ini siswa dapat mengembangkan kreatifitas, kemampuan, dan daya pemecah masalah menurut kehendaknya sendiri, mampu meningkatkan pemahaman siswa dalam materi yang menjadi tanggung jawabnya, menumbuhkan hubungan yang harmonis antara guru dan siswa sehingga suasana belajar menjadi sangat akrab, serta mengatasi masalah kebosanan saat proses pembelajaran berlangsung. Penggunaan model pembelajaran JIGSAW mengharapkan siswa secara individual berbagi kemampuan dalam berbagai aspek kerja yang berbeda.

\section{METODE}

Penelitian ini dilakukan di SMA Negeri 1 Kademangan, Kabupaten Blitar. Subjek penelitian ini adalah siswa kelas X.3 dengan jumlah 30 siswa yang terdiri dari 11 siswa lakilaki dan 19 siswa perempuan. Waktu penelitian dilaksanakan pada bulan Mei sampai Juni 2016 pada semester genap.

Prosedur penelitian ini dilakukan melalui empat tahap yaitu: Planning (perencanaan), kemudian diteruskan tindakan Acting (pelaksanaan), Observing (pengamatan), kemudian dilanjutkan pada tahap Reflecting (refleksi), (Kemmis dan Mc Taggart dalam Tampubolon (2003). Teknik pengumpulan data yang digunakan dalam penelitian ini adalah: wawancara, observasi, dan tes.Sumber data dalam penelitian ini adalah siswa kelas X.3 SMA Negeri 1 Kademangan, untuk memperoleh data tentang pemahaman konsep geografi pada materi dinamika hidrosfer dengan Penerapan model pembelajaran JIGSAW. Data yang diperoleh dalam penelitian ini berasal dari hasil observasi dan nilai tes pemahaman yang diberikan di setiap akhir siklus. Data yang diperoleh dijelaskan secara rinci sesuai dengan temuan dilapangan.

\section{Pemahaman konsep awal}

\section{HASIL DAN PEMBAHASAN}

Data pemahaman awal diperoleh dari nilai tes terakhir sebelum materi Dinamika Hidrosfer diajarkan.Data pemahaman awal siswa dapat dilihat pada tabel 1 berikut ini.

Tabel 1 Distribusi nilai pemahaman siswa sebelum tindakan pembelajaran menggunakan model pembelajaran JIGSAW.

\begin{tabular}{|c|c|c|}
\hline Rentang nilai & Kriteria & Siswa \\
\hline $85-100$ & Sangat baik & 14 \\
\hline $75-84$ & Baik & 2 \\
\hline $60-74$ & Sedang & 5 \\
\hline $45-59$ & Kurang & 6 \\
\hline$<45$ & Sangat kurang & 3 \\
\hline \multicolumn{2}{|c|}{ Jumlah } & 30 \\
\hline
\end{tabular}


Dari tabel 4.1 di atas, menunjukkan bahwa sebanyak 14 siswa di kelas X.3 mendapatkan nilai pemahaman konsep dengan kriteria sangat baik. Siswa yang mendapat nilai pemahaman konsep dengan kriteria baik sebanyak 2 siswa. selain itu, siswa yang mendapatkan nilai pemahaman konsep dengan kriteria sedang sebanyak 5 siswa, siswa yang mendapatkan nilai pemahaman konsep dengan kriteria kurang sebanyak 3 siswa, dan siswa yang mendapatkan nilai pemahaman konsep dengan kriteria sangat kurang sebanyak 3 siswa.

\section{Pemahaman konsep siklus I}

Data hasil pemahaman konsep siklus I diperoleh dari hasil tes pada akhir siklus I. data pemahaman konsep siswa siklus I dapat dilihat pada tabel 2 berikut ini.

Tabel 2 Distribusi nilai pemahaman siswa siklus I

\begin{tabular}{|c|c|c|}
\hline Rentang nilai & Kriteria & Siswa \\
\hline $85-100$ & Sangat baik & 8 \\
\hline $75-84$ & Baik & 8 \\
\hline $60-74$ & Sedang & 12 \\
\hline $45-59$ & Kurang & 1 \\
\hline$<45$ & Sangat kurang & - \\
\hline \multicolumn{2}{|c|}{ Jumlah } & 30 \\
\hline
\end{tabular}

Berdasarkan tabel 2 dapat dilihat bahwa tidak satupun siswa mendapatkan nilai dibawah 45. Sementara itu, siswa yang memperoleh nilai pemahaman konsep dengan kriteria sangat baik dan baik masing-masing sebanyak 8 siswa. Siswa yang memperoleh nilai pemahaman konsep dengan kriteria sedang sebanyak 12 siswa, dan siswa yang memperoleh nilai pemahaman konsep dengan kriteria kurang hanya 1 siswa.Sama halnya dengan sebelum tindakan, siswa yang yang memperoleh nilai dibawah KKM sebanyak 14 siswa. Namun, siswa yang mendapat nilai pemahaman konsep dengan kriteria kurang semakin berkurang jumlahnya, bahkan pada siklus ini tidak ada siswa yang memperoleh nilai pemahaman konsep dengan kriteria sangat kurang.

\section{Pemahaman konsep siklus II}

Data hasil pemahaman konsep siklus II diperoleh dari hasil tes pada akhir siklus I. data pemahaman konsep siswa siklus II dapat dilihat pada tabel 3 berikut ini.

Tabel 3 distribusi nilai pemahaman siswa siklus II.

\begin{tabular}{|c|c|c|}
\hline Rentang nilai & Kriteria & Siswa \\
\hline $85-100$ & Sangat baik & 9 \\
\hline $75-84$ & Baik & 16 \\
\hline $60-74$ & Sedang & 5 \\
\hline $45-59$ & Kurang & - \\
\hline$<45$ & Sangat kurang & - \\
\hline \multicolumn{2}{|c|}{ Jumlah } & 30 \\
\hline
\end{tabular}

Berdasarkan tabel 3 menunjukkan bahwa tidak ada satupun siswa yang mendapatkan nilai pemahaman konsep dengan kriteria kurang dan sangat kurang. Siswa yang memperoleh nilai pemahaman konsep dengan kriteria sangat baik sebanyak 9 siswa. Siswa yang memperoleh nilai pemahaman konsep dengan kriteria baik sebanyak 16 siswa, dan siswa yang memperoleh nilai pemahaman konsep dengan kriteria sedang sebanyak 5 siswa. Terdapat peningkatan pemahaman siswa dari siklus sebelumnya, hal tersebut dibuktikan 
dengan bertambahnya nilai pemahaman siswa yang mencapai KKM, yaitu sebanyak 25 siswa.

Temuan dalam penelitian ini menunjukkan bahwa Pembelajaran dengan menerapkan model JIGSAW dapat meningkatkan pemahaman konsep geografi siswa.Peningkatan pemahaman siswa dapat dilihat dari peningkatan pemahaman awal hingga pemahaman pada siklus II.Peningkatan pemahaman tersebut dapat dilihat dari tabel 4 berikut.

Tabel 4 Peningkatan pemahaman konsep siswa

\begin{tabular}{lccc}
\hline \multicolumn{1}{c}{ Tahapan } & Rata-rata & Peningkatan pemahaman & Presentase \\
\hline Sebelum tindakan & 72,22 & - & \\
Siklus I & 74,16 & 1,94 & $2,68 \%$ \\
Siklus II & 78,83 & 4,67 & $6,29 \%$ \\
\hline
\end{tabular}

Dari tabel 4.7 diatas dapat diketahui bahwa terdapat peningkatan pemahaman konsep siswa pada setiap siklusnya. Sebelum tindakan nilai rata-rata siswa hanya mencapai 72,22, kemudian setelah dilakukan tindakan siklus I rata-rata pemahaman konsep siswa meningkat menjadi 74,16 . Itu berarti telah terjadi peningkatan rata-rata pemahaman konsep siswa sebesar 1,94 atau 2,60\%. Rata-rata pemahaman konsep pada siklus I dan siklus II juga telah mengalami peningkatan yaitu dari 74,16 menjadi 78,83. Hal itu, berarti telah terjadi peningkatan dari rata-rata pemahaman konsep siswa sebesar 4.67 atau $6.29 \%$. Jadi, pemahaman konsep siswa kelas X.3 SMA Negeri 1 Kademangan dapat meningkat dengan penerapan model pembelajaran JIGSAW. Hal ini juga sesuai dengan pendapat Haryani (2012), yaitu terdapat peningkatan pemahaman konsep siswa dengan menerapkan model pembelajaran JIGSAW. Firdausy (2014) juga mengemukakan bahwa pembelajaran kooperatif $J I G S A W$ juga mampu meningkatkan pemahaman konsep siswa.

Perbedaan penelitian ini dengan penelitian Haryani (2012) yaitu penelitian ini menggunakan II siklus sedangkan penelitian Haryani (2012) menggunakan III siklus.Penelitian ini mengukur satu variabel yaitu pemahaman konsep sedangkan penelitian Haryani (2012) mengukur dua variabel yaitu motivasi dan pemahaman konsep.Hasil penelitian Haryani (2012), yaitu rata-rata pemahaman konsep siswa pada siklus I dari $69 \%$ meningkat menjadi $81 \%$ di siklus II dan meningkat menjadi $94 \%$ di siklus III. Sedangkan penelitian ini, rata-rata pemahaman konsep siswa dari siklus I sebesar 74,16 meningkat sebanyak $6,29 \%$ menjadi 78,83 pada siklus II. Perbedaan penelitian ini dengan penelitian Firdausy (2014) yaitu, menunjukkan bahwa pemahaman konsep siswa dengan rata-rata nilai pada siklus I sebesar 74,5 dan rata-rata nilainya meningkat menjadi 81,07 pada siklus II. Sedangkan penelitian ini pada siklus I memiliki rata-rata nilai 74,16 dan 78,83 pada siklus II.

Pembelajaran dengan menerapkan model JIGSAW dapat meningkatkan pemahaman konsep geografi siswa, karena dengan model ini siswa secara individu didalam kelompoknya dituntut untuk bertanggung jawab menyelesaikan tugas yang telah didapat dan saling membantu anggotanya untuk memahami hasil diskusi. Sehingga, semua anggota dapat memahami apa yang telah didiskusikannya. Hal ini dikemukakan oleh Arends (1997) dalam Tiwan (2008). Kelebihan model JIGSAW menurut Shohimin (2014:93) yaitu: I) Memungkinkan murid dapat mengembangkan kreativitas, kemampuan, dan daya pemecah masalah menurut kehendaknya sendiri; II) Hubungan antara guru dan murid berjalan seimbang dan memungkinkan suasana belajar menjadi sangat akrab sehingga memungkinkan hubungan yang harmonis; III) Memotifasi guru untuk bekerja lebih aktif dan efektif. Mampu memadukan berbagai pendekatan belajar, yaitu pendekatan kelas, kelompok, dan individual. 
Dari pembahasan di atas dapat diketahui bahwa memang benar penerapan model pembelajaran JIGSAW dapat meningkatkan pemahaman konsep geografi pada siswa kelas X.3.Namun, tidak semua siswa cocok belajar dengan penerapan model pembelajaran $J I G S A W$. Jadi untuk membuat siswa agar selalu aktif dan antusias di setiap kegiatan belajar dperlukan variasi model pembelajaran.

\section{KESIMPULAN}

Berdasarkan rumusan masalah dan hasil penelitian dapat disimpulkan bahwa, penerapan model pembelajaran JIGSAW dapat meningkatkan pemahaman konsep geografi pada materi dinamika hidrosfer siswa kelas X.3 SMA Negeri 1 Kademangan. Hal tersebut dapat dilihat dari adanya peningkatan nilai pemahaman konsep siswa yang dilihat dari nilai pemahaman sebelum tindakan, dan dari tes pemahaman yang dilaksanakan setiap akhir siklus, baik siklus I maupun siklus II.

\section{DAFTAR RUJUKAN}

Firdausy, Vionita. 2014. Penerapan Model Pembelajaran Kooperatif Tipe Jigsaw untuk Meningkatkan Pemahaman Konsep Siswa Pada Mata pelajaran Geografi Dikelas $X$ Sosial 2 SMAN 5 Malang. Skripsi tidak diterbitkan. Malang: Universitas Negeri Malang.

Haryani, Fitri. 2012. Meningkatkan motivasi dan pemahaman konsep perbandingan fungsi trigonometri melalui model pembelajaran JIGSAW di SMA Negeri 8 kota Jambi. (online),http://unja.ac.id. Diakses pada tanggal 1 Maret 2016.

Purwanto, Edy. 2013. Strategi Pembelajaran Bidang Studi Geografi. Malang: Universitas Negeri Malang (UM PRESS).

Sagala, Syaiful. 2012. Konsep Dan Makna Pembelajaran Untuk Membantu Memecahkan Problematika Belajar Dan Mengajar. Bandung : ALFABETA.

Shohimin, Aris. 2014. 68 Model Pembelajaran Inovatif Dalam Kurikulum 2013. Yogyakarta: Ar-Ruzz Media.

Sumarmi. 2012. Model-Model Pembelajaran Geografi. Malang: ADITYA MEDIA PUBLISHING.

Tampubolon, Saur. 2013. Penelitian Tindakan Kelas sebagai Pengembangan Profesi Pendidikan Dan Keilmuan.Jakarta: Erlangga.

Tiwan. 2008. Peningkatan Kualitas Proses dan Hasil Pembelajaran Bahan Teknik Melalui Penerapan Pembelajaran Kooperatif Model JIGSAW. (Online), http ://staff .uny.ac.id. Diakses pada 24 Januari 2016.

Winkel, W.S. 1996. Psikologi Pengajaran. Jakarta: PT Gramedia Widiasarana. 